\title{
Identifying Reading Preferences of Secondary School Students
}

\author{
Irshad Hussain $^{1}$, Parveen Munshi ${ }^{2}$ \\ ${ }^{1}$ Department of Education, The Islamia University of Bahawalpur, Bahawalpur, Pakistan; \\ ${ }^{2}$ Faculty of Education, University of Sindh Hyderabad, Pakistan. \\ Email: irshad.hussain@iub.edu.pk, irshad_iub@yahoo.com \\ Received October $3^{\text {rd }}, 2011$; revised November $16^{\text {th }}, 2011$; accepted November $21^{\text {st }}, 2011$.
}

\begin{abstract}
The present study was conducted with the main purpose of identifying reading preferences of secondary school students and their related issues. The study was conducted on a total of 387 secondary school students of academic session 2010-12 in District Bahawalpur of Pakistan. Qualitative and quantitative data were collected through questionnaire and interview schedule respectively by adopting survey method. The study concluded that secondary school students preferred to read books, magazines, poetry and other reading materials to get pleasure through edutainment, kill their leisure time during holidays and/or at weekends and for their emotional gratification. The respondents preferred to read books on religion, literature, novels, magazines and story \& romantic books. They were keen on reading newspaper, traveling story and scientific books, autobiographies and literature poetry and drama. They faced problems in reading and setting their reading preferences like high costs of the books, context and circumstances, availability of books, time and their time management ability, examinations \& academic workload, lack of guidance, personal interest, and their study circles or groups.
\end{abstract}

Keywords: Adolescents, Edutainment, Guidance, Intelligentsia, Reading Preferences

\section{Introduction}

\section{Perspective and Importance of Reading}

Reading appears to be a dynamic process and it involves readers actively to enhance their vocabulary and level of information. It is a process of communication between writer and reader. To put it another way one can say that it is an art of decoding and construing message under and through the wordswritten materials. Smith and Robinson (1980) defined it simply as to be an endeavor of reader to understand message of the writer. Generally, reading and reading habits are used to describe different attributes of the readers. Basically, reading is an intellectual activity which actively involves readers to understand and process information; whereas reading habit is regarded as a psychological attribute of one's personality (Sharma and Singh, 2005). Like other habits reading habit may take time to develop as an attribute of one's personality.

Ögeyik, M. C., \& Akyay, E. (2009) viewed reading as a significant process in ones' academic life leading towards knowledge. It guides individuals to develop creativity and critical thinking. Reading and reading habit help readers satisfy their personal needs, enhance level of maturity and ensure freedom of opinion formation \& reflection. Opinion formation and reflection is a critical process and demands a blend of vision and wisdom for which adolescents are wished for.

Different motives promote reading and reading habits among young children and adolescents. Their interests and context can be considered to be the basic motives which urge them to acquire information and knowledge. The urge for acquiring information and knowledge leads them to read books, newspapers, novels, research papers and articles etc. It indicates their reading preferences. Reading preferences of all individuals may be different according to their specific age group(s) and need(s) of information. Apparently, they need someone to help in selecting book(s) to read according to their age, interest and intellectual capability. However, teachers can help young children and adolescents to select appropriate book(s) by knowing their reading preferences, maturity level \& mindset, socio-cultural and family background. Teachers can motivate and guide them to select and read books that best meet their academic and emotional needs.

\section{Context of Setting Reading Preferences}

Naturally, all individuals are different with their respective potential to read and understand the information. The adolescents' interest in reading books and their contexts indicate the type and process of acquiring information. Elliott (2006) conducted a meta-analysis of studies on reading and found attitude of adolescents toward new information to be on a continuum with childhood, and varied progress exclusive of specific age group. Adolescents have a natural tendency to idealize and fantasize characters and personalities. Therefore, their selection of books for reading to learn seems to be contextual associated with socio-cultural and geo-political conditions (Ayyıldız, Bozkurt, \& Canll, 2006) arising from some uncertain events. For example people of all age groups in Pakistan appeared to be interested in reading books on Former President of Iraq Saddam Hussain during America's invasion on Iraq in 1990s. Similarly, people all over the world started reading books on Islam after the emergence of Taliban and American attack on them in Afghanistan. Millions of people were reported to be reading papers, articles, and books on Islam even in Europe and America itself. Likewise, books on Zulfeqar Ali Bhutto and Benazir Bhutto grabbed the market sale after their assassination respectively. The scandal book on secret romance of Monica Lewinsky with Clinton (Monica Story) appeared to be an open romantic book which attracted the adolescents and young adults' at large scale. These are a few examples which indicate context of reading preferences and information acquiring attitude of adolescents and older people.

\section{Reading Preferences of Adolescents and Secondary School Students}

Physiologically and psychologically human life is divided 
into different developmental stages each corresponding to specific age group - toddler and infancy (birth to three years) to older adult (80 years and above) age groups (http://www.techgroupin.com). However, in Pakistan, secondary school students who are 14 - 18 years old (Hussain, 2009) belong to adolescent (13 - 20 years http://www.techgroupin.com) age group. They seem to be imaginary having idealistic approach with a little perception of the real world around. They tend to seek ideals and show their interest in opposite gender. Adolescence appears to be volatile period of one's life which may mislead youngsters in blossoming emotions. Different tendencies are usually observed in different students even in the same class and/or school-these may be positive as well as negative. Therefore, they need guidance and counseling to divert their emotions in right direction at the right time. Their reading preferences and selection of books may be set according to their aptitude and needs through mutual negotiation.

Generally speaking, adolescents love to read books for pleasure and edutainment-education through fun. This edutainment blended with wittiness may influence their reading preferences. More or less, all individuals are likely to have the sense of humor and wittiness. Therefore, the books on humor appeal to the people irrespective of their age (Greenlaw \& Wielan, 1979) groups but adolescents seem to be more inclined toward them. They love reading poetry, adventurous \& mysterious novels and comic books. They prefer to idealize romantic, brave, humorous, and adventurous characters with an inclination to adopt. A few may read newspapers and magazines, but these are scarcely available in Pakistani schools particularly for students.

\section{Review of Related Studies}

Reading preferences and interests of young children and adolescents studying at different levels have been addressed by many researchers the world over. For example, the study conducted by Worthy (1999) addressed the reading preferences of elementary school students. It revealed that the students of grade- 6 preferred to read story books, cartoons, comics, popular magazines, and sports even though these books were rarely available in school libraries. When young children get mature, their intellectual faculties develop and they wish to see the world practically. Ley, Schaer and Dismukes (1994) asserted that elementary students (grades six through eight) were eager to read more for practical life and less for individual development or enjoyment. Therefore, it can be said that curiosity to know and desire to fantasize the characters enhances reading and reading habits of young children and adolescents.

The study of (McGinley \& Kamberelis, 1996) concluded that the younger children in grades three and four read books for recreation and fun. It may give them pleasure and they tend to learn with amusement. Young children are always curious and they seem to be enthusiastic to observe the nature and natural environment. They take interest in different objects particularly, birds, animals, butterflies and flowers. Graham (1986) affirmed it by asserting that they (young children studying in grades 3 \& 4) were more interested in animals \& nature and wished for reading adventurous and story books. The gender-wise divide of interest was investigated by Wolfson, and Manning, and Manning (1984) and found that boys strongly preferred nonfiction whereas their counterparts did show their stronger preferences for realistic fiction. However, the [Gouvernement du] Québec (2005) survey found that girls read more books and magazines and they had a greater tendency to read for longer duration. But, their counterparts preferred comic \& humour books and they appeared to be more interested in reading science fiction, scientific information and sports pages in newspapers. But in schools, students were advised to read textbooks with wishful choice of other books. Similarly, the studies of Bundy (1983) and Hawkins (1983) revealed that intermediate students showed their interest in reading books on history and science, however, some of them enjoyed reading mysterious and adventurous books and autobiographies of great people. Generally, young children are likely to take interest in comic books, and adventure and mystery novels.

\section{Factors Affecting Reading Preferences}

Different factors seem to be responsible for limiting reading preferences of school children and adolescents. Among others, the assessment system may be regarded more important. In Pakistan assessment system consists of paper pencil tests which compel students to study their textbooks for higher grades. They are advised to do homework (course assignments) and prepare for the examinations. It limits their extensive reading (Todd, 2003). They may not become good readers and wish for satisfactory grades. Inadequate or less reading may lower the performance and grades of students in schools. The study conducted by Nielsen (2005) supported it by affirming an inadequate reading skill as one of the factors responsible for teens' poor performance.

Similarly, some factors may effect on selection of books. Burgess (1985) found that young and adolescent students tend to select books according to their favorite authors. Appearance of the book-cover and title page, illustrations, content of the first page, and its length has a significant effect on such students. However, Wilson (1985) linked these factors with lower achieving students and asserted that they preferred romantic, original, brave, funny, bold and adventurous characters. Subject matter of the book, its cover page and outlines apparently has significant signify their choice of reading material.

\section{Rationale of the Study}

The available literature indicates that reading preferences of young school children and adolescents have been a hot topic in developed countries over decades (Todd, 2003). However, a narrow scale of such studies appears in the context of Pakistan which led to conduct the study.

\section{Objectives of the Study}

The present study was conducted with the following objectives:

1) To identify reading preferences of secondary school students.

2) To find out the purpose of their reading books and/other materials

3) To examine the problems and factors affecting reading preferences of secondary school students.

\section{Research Methodology}

This study addressed the prevailing situation of reading and reading preferences of secondary school students in District Bahawalpur of Pakistan. Therefore, the researchers used survey 
method of descriptive research for data collection. The study was delimited to male secondary schools only. The population of the study consisted on secondary school students (male) of Bahawalpur District Academic Session 2010-12. The researchers adopted qualitative and quantitative approaches to find out the real situation of the phenomenon under study. They used convenient sampling technique and collected quantitative data from 387 students and 12 secondary schools. They collected quantitative data by administering a questionnaire prepared on five-point rating (likert) scale and finalized after pilot testing. The questionnaires were administered through head teachers of the respective secondary schools.

Similarly, the researchers collected qualitative data from 238 students through focused group interview technique by using an interview schedule. The participants/respondents of the study were briefed about its objectives and interviewed in groups at their respective schools. The responses of the participants (interviewees) were recorded and analyzed qualitatively and that of quantitative responses/data through percentage for arriving at conclusions. However, all of the respondents participated on volunteer basis in the study.

\section{Data Analysis and Results of the Study}

\section{Quantitative Data Analysis and Results}

The results of quantitative data are presented in tables which are given below.

\section{Reading Preferences of Secondary School Students}

The data given in the Table 1 revealed that there were different motives which inspired secondary school students to set their reading preferences and select books. According to the data secondary school students preferred to read books, magazines, poetry and other reading materials to get pleasure (80\%) through edutainment for enhancing their learning (90\%) for life and attitude to gain and/or construct new knowledge (92\%) blending information with their personal experience and/or life. Similarly, they wished to read books and other reading materials to kill their leisure time (71\%) during holidays and/or at weekends, and adopted reading as their pastime hobby (65\%) along with regular course of study. Secondary school students appeared to be imaginary and sentimental therefore, they (65\%) showed their interest in reading for their emotional gratification for developing balanced personality and stability in life. How- ever, they (67\%) appeared not to read for snobbery or pretentiousness which indicated that secondary school students were mature readers keen on construing the concepts, information and/ or knowledge.

\section{Types of Books Which Secondary School Students Prefer to Read}

Table 2 described the reading preferences of secondary school students. The respondents of the study were Muslims and therefore, they preferred religious books (87\%) foe reading to get information about religious life. They were found to be interested in reading literary books (85\%), novels, story books and romantic literature (55\%, 88\% and $81 \%$ respectively). The data affirmed that they were keen on reading informative books and materials like newspaper (65\%), traveling story (79\%) and scientific books (99\%) to enhance their knowledge and level of information. The Secondary school students appeared to have tendency of idealizing personalities and characters and therefore, they desired to read autobiographies (75\%) and magazines (89\%). However, the data confirmed that they had aesthetic sense to enjoy the colours of life by reading poetry (romantic $95 \%$; classical $65 \%$ ) in local or national languages, and drama (comedy 75\%; tragedy only 40\%).

\section{Source of Guidance to Select Reading Materials}

The Table 3 presented the data on opinion of secondary school students about their source of guidance for selecting reading materials. The data reflected that secondary school students were of the opinion that they needed guidance in selecting good reading books/materials which they desired to seek from their teachers (88\%), parents $(79 \%)$ and friends or study mates (82\%). However, in the age of media and technology they (72\%) also came to know about some of the famous books and/or magazines, novels etc. through their advertisements in electronic or print media and they (71\%) themselves selected such books/materials to read.

\section{Problems and Factors Affecting Their Reading Preferences of Secondary Students}

Table 4 reflected different factors which affected the reading preferences of secondary school students. They pointed out various reasons and factors which affected their reading and reading preferences like high costs of the books and/or other reading materials (92\%) and their low purchasing power, con-

Table 1.

Opinion of secondary school students about their reading preferences.

\begin{tabular}{|c|c|c|c|c|c|}
\hline \multirow{2}{*}{ Sub themes } & \multicolumn{5}{|c|}{ Level of Agreement (Percentage of respective frequencies is given in parentheses) } \\
\hline & SA & A & UNC & DA & SDA \\
\hline Read for learning & $211(54.5)$ & 139 (35.9) & 0 & $21(5.4)$ & $16(4.1)$ \\
\hline Read for knowing/Knowledge & $191(49.4)$ & 166 (42.9) & $2(0.5)$ & $23(5.9)$ & $5(1.3)$ \\
\hline Read to kill the time & $141(36.4)$ & $132(34.1)$ & $8(2.1)$ & $66(17.1)$ & $40(10.3)$ \\
\hline Reading as hobby & $97(25.1)$ & $156(40.3)$ & $3(0.8)$ & 77 (19.9) & $54(14.0)$ \\
\hline Emotional satisfaction & $111(28.7)$ & 139 (35.9) & $4(1.0)$ & 94 (24.3) & $39(10.1)$ \\
\hline Read for snobbery & $38(9.8)$ & 81 (20.9) & $8(2.1)$ & $148(38.2)$ & $112(28.9)$ \\
\hline
\end{tabular}


Table 2.

Opinion of Secondary School Students about the types of Books which they preferred to read.

\begin{tabular}{|c|c|c|c|c|c|}
\hline \multirow{2}{*}{ Sub themes } & \multicolumn{5}{|c|}{ Level of Agreement (Percentage of respective frequencies is given in parentheses) } \\
\hline & SA & A & UNC & DA & SDA \\
\hline Religious books & 199 (51.4) & $138(35.7)$ & $4(1.0)$ & $26(6.7)$ & $20(5.2)$ \\
\hline Literary books & $172(44.4)$ & $156(40.3)$ & $6(1.6)$ & $36(9.3)$ & $17(4.4)$ \\
\hline Novels & $99(25.6)$ & $114(29.5)$ & $2(0.5)$ & $98(25.3)$ & $74(19.1)$ \\
\hline Story books & $213(55.0)$ & $126(32.6)$ & $2(0.5)$ & $28(7.2)$ & $18(4.7)$ \\
\hline Romantic literature & $171(44.2)$ & $144(37.2)$ & $2(0.5)$ & $23(5.9)$ & 47 (12.1) \\
\hline Newspapers & 117 (30.2) & $134(34.6)$ & $6(1.6)$ & 87 (22.5) & 43 (11.1) \\
\hline Traveling story & 167 (43.2) & 138 (35.7) & $2(0.5)$ & $33(8.5)$ & 47 (12.1) \\
\hline Magazines & 189 (48.8) & $156(40.3)$ & $4(1.0)$ & $26(6.7)$ & $12(3.1)$ \\
\hline Romantic poetry & $171(44.2)$ & $198(51.2)$ & 0 & $12(3.1)$ & $6(1.6)$ \\
\hline Classical poetry & 98 (25.3) & 154 (39.8) & $2(0.5)$ & 77 (19.9) & $56(14.5)$ \\
\hline Scientific books & 187 (48.3) & $198(51.2)$ & 0 & $2(0.5)$ & 0 \\
\hline Autobiographies & $133(34.4)$ & 161 (41.6) & $2(0.5)$ & 77 (19.9) & $14(3.6)$ \\
\hline Comedy Drama & $181(46.8)$ & $106(27.4)$ & $2(0.5)$ & 46 (11.9) & $52(13.4)$ \\
\hline Tragedy drama & 67 (17.3) & 88 (22.7) & $4(1.0)$ & $117(30.2)$ & 111 (28.7) \\
\hline
\end{tabular}

Table 3.

Opinion of secondary school students about their source of guidance for selecting reading materials.

\begin{tabular}{|c|c|c|c|c|c|}
\hline \multirow{2}{*}{ Sub themes } & \multicolumn{5}{|c|}{ Level of Agreement (Percentage of respective frequencies is given in parentheses) } \\
\hline & SA & A & UNC & DA & SDA \\
\hline Teachers & $213(55.0)$ & $126(32.6)$ & $2(0.5)$ & $28(7.2)$ & $18(4.7)$ \\
\hline Parents & $112(28.9)$ & $188(48.6)$ & $4(1.0)$ & $56(14.5)$ & $27(7.0)$ \\
\hline Friends & $202(52.2)$ & $114(29.5)$ & $2(0.5)$ & $29(7.5)$ & $40(10.3)$ \\
\hline Advertisements-media & $122(31.5)$ & $158(40.8)$ & $6(1.6)$ & $53(13.7)$ & $48(12.4)$ \\
\hline Self-selection & 127 (32.8) & 148 (38.2) & $8(2.1)$ & $37(9.6)$ & 67 (17.3) \\
\hline
\end{tabular}

Table 4.

Opinion of secondary school students about problems and factors affecting their reading preferences.

\begin{tabular}{|c|c|c|c|c|c|}
\hline \multirow{2}{*}{ Sub themes } & \multicolumn{5}{|c|}{ Level of Agreement (Percentage of respective frequencies is given in parentheses) } \\
\hline & SA & A & UNC & DA & SDA \\
\hline Context & 166 (42.9) & $187(48.3)$ & $4(1.0)$ & $24(6.2)$ & $6(1.6)$ \\
\hline Availability of books & $171(44.2)$ & $111(28.7)$ & 0 & $46(11.9)$ & $59(15.2)$ \\
\hline Time and time management & $211(54.5)$ & 129 (33.3) & $2(0.5)$ & $26(6.7)$ & 19 (4.9) \\
\hline Examinations & 199 (51.4) & 122 (31.5) & 0 & 23 (5.9) & $43(11.1)$ \\
\hline Lack of guidance & $132(34.1)$ & 114 (29.5) & $4(1.0)$ & $84(21.7)$ & $53(13.7)$ \\
\hline Personal interest & $148(38.2)$ & $161(41.6)$ & 0 & $32(8.3)$ & 46 (11.9) \\
\hline Study circles/groups & 166 (42.9) & 142 (36.7) & $2(0.5)$ & 57 (14.7) & $20(5.2)$ \\
\hline
\end{tabular}


text and circumstances at national or international level (91\%) motivating them towards reading a specific book/article/paper etc., and availability of such books (73\%) in the schools' library and market which they ever wished for. Similarly, some other factors appeared to have an impact on reading preferences of secondary school students - time and their time management ability (88\%), examinations and their preparation (83\%) and workload and number of courses being taught in the school (80\%). Besides of all these elements lack of guidance (64\%), lack of personal interest (80\%) and reading taste of study circles or study groups (80\%) appeared to be most important factors to have an impact on reading and setting reading preferences of secondary school students.

\section{Results of Qualitative Data Analysis}

The participants revealed interesting facts about reading facilities and their preferences, their problems and needs of guidance in selecting books for reading. During the interview the participants explained their reading interests and motives.

There were different reasons which usually made secondary school students read different books of their interests. Majority of the respondents from all of the sampled schools asserted, "We read to know. Books give us new knowledge and information about cultures and countries, people and places, innovations and inventions, discoveries and geography, science and technology, and fiction and realities of and about life. We read for pleasure and fun. We have aesthetic sense and read poetry and books on humor and comedy, adventure, travel stories (SAFAR NAMA), love and romantic stories, scientific and general knowledge."

Pakistan is Muslim Country and therefore, all (100\%) of the respondents were Muslims. It is obligatory for all Muslims to have basic knowledge of and about the fundamentals of Islam. Reading enhances level of information and knowledge of the reader(s). Reading in groups/reading circles or clubs and sharing promotes passion for reading competition helping readers select good books. The respondents were of the voice, "We share information and exchange books to read in our friends' reading circles/club. We read books on Islam to learn its basic and fundamental principles, dos' \& don'ts, life and achievements of Muslim heroes. It instills us to go ahead and lead to live a civilized life of a true Muslim citizen."

After graduating, the secondary school students are expected to assume the social responsibilities of an adult. Therefore, they seem to be entering into real life perceiving its facts and realities-pleasures and pains. They need to develop scientific attitude and critical thinking for living a progressive and successful life. An obvious majority of the respondents stated, "Reading books on science and scientific inventions promotes rationality in our thinking. It leads us towards developing scientific attitude even in our social life. It helps us avoid superstitions and we try to seek specific cause to every happening in life. It helps us differentiate between right and wrong."

They further asserted, "Reading a new book helps us in enhancing our vocabulary. We come to know the meaning of new words, phrases and phrasal verbs with context of their use. It gives direction to our thinking leading to actions and resulting in our accepted attitudes and behaviors."

It is generally said that beauty is an artistic phenomenon which comes from one's inside. It is reflected in terms of aesthetic and poetic styles. The respondents' age group is assumed to be full of hopes and aspirations and they seem to be inter- ested in reading poetry and lovely reading materials. Secondary school students showed their aesthetic sense by indicating, "Books on poetry enhance our aesthetic sense which leads us to see the world in beautified and optimistic way and we can feel the beauty of nature around us. It prepares us to feel the pleasures and pains of real life and to express same in heart loving manner. It helps us to set high hopes for overcoming desperation."

Naturally human being seeks guidance to live a successful and productive life and historically has been following someone as ideal. There are different great leaders, thinkers \& philosophers, reformers and scholars whom people idealize and love to follow. The respondents expressed their love for their ideals and they preferred books such great personalities. They were of the view, "Books on heroes in history inspire us not only to set high aims but also to struggle for higher achievements in life. We idealize these personalities and learn how to follow them and spread their message/ideology and/or philosophy to help people get out of their miseries."

In Pakistan secondary schools have scarce reading facilities. Different factors seem to be responsible for such deficiency and create lot of problems for students. The students articulated a number of factors which hindered their reading. They voiced, "We do not have a proper library in school. Our school library consists of two or three almirahs in a classroom, staff room and/or science laboratory having a few old torn off books which are not issued to us. We spend library period in school without reading even a newspaper. Access to newspaper is limited to teachers only and in some schools it is rarely available."

In schools students have to study different courses/textbooks according to academic calendar. They have to go for home tuition and prepare for the annual and/ or final examination to get high marks. I such circumstances they have less time for reading other than their textbooks or notes prepared for the getting through the examination. It effects on their reading and reading preferences. Most of the respondents explained it as, "We have to cover the courses and complete home work of almost all (eight/ten) subjects. It takes too much time to read a book other than a textbook/course book. Similarly, we have to go for home tuition and prepare for getting through final examination thinking scarcely about extra reading — novel, poetry, history, magazine and/or newspaper."

General knowledge appears to be necessary for every individual of society but secondary school students are expected to acquire basic information about their country, people \& places and every day science. It can be promoted by arranging class competitions. But students indicated the situation by expressing, "A fewer literary competitions are organized in our schools. In a way we are kept away from books on general knowledge, science and geography."

Guidance is necessary for everyone in life but secondary school students need proper guidance in selecting books to read. Such guidance is rarely provided in schools which results in poor reading and readability of students. In almost all of the sampled schools the respondents recorded their reservations by saying, "No one guides us what to read and why. Consequently we read what we have or come across and think better for us. Teachers emphasize on completion of courseltextbooks and home work; parents expect high scores and always advise to keep on preparing for the examinations banning on extra reading even a newspaper."

In short, the respondents appeared to be very keen on reading and they showed their reading preferences in almost all aca- 
demic areas including religion and scientific books. They seemed to be assertive in describing their problems and factors which affected on their reading and reading preferences - cost of books, covering syllabi and preparing for examinations etc.

\section{Conclusion}

In overall, the respondents expressed their diversified reading preferences. Generally, they preferred to read books on Islam, traveling stories, science and literature-novels, and romantic stories \& books, autobiographies, poetry and newspaper \& magazines. They read such materials for getting pleasure through edutainment killing their leisure time and adopting it as pastime hobby for emotional gratification. However, their parents, teachers and friends helped and advised them select books to read according to their age and context. Likewise, different factors impacted on their reading and they faced lot of problems like poor conditions of school libraries, workload, cost and availability of books, personal interests and time \& time management etc.

\section{References}

Ayyıldız, M., Bozkurt, Ü., \& Canli, S. (2006). Okuma Kültürü Üzerine Bir Araștırma. URL (last cheked 19 November 2008) http://yayim.meb.gov.tr/dergiler/169/mustafa.pdf

Bundy, B. A. (1983). The development of a survey to ascertain the reading preferences of fourth, fifth, and sixth graders. Dissertation Abstracts International 44, University Microfilms No. DA 8312392.

Burgess, S. A. (1985). Reading but not literate: The child read survey. School Library Journal, 31, 27-30.

Elliott, M. (2006). Information seeking behavior-Adolescents. Essay, Information Seeking Behavior, Pathfinder Project, IS 245-Winter, $1-13$.

Graham, S. A. (1986). Assessing reading preferences: A new approach. New England Reading Association Journal, 21, 811.

Greenlaw, M. J., \& Wielan, O. P. (1979). Reading interests revisited. Language Arts, 56, 432-433.

Gouvernement du Québec (2005). Profiles of secondary School readers:
Concerted action to support Reading research. Ministère de l'Éducation, du Loisir et du Sport, 2005.

www.mels.gouv.qc.ca/publications/menu-rapports.htm

Hawkins, S. (1983). Reading interests of gifted children. Reading Horizons, 24,1822

Hussain, I. (2009). A chapter on secondary school external examination systems: A case study of Pakistan. In B. Vlaardingerbroek, \& N. Taylor, (Eds.) Secondary school external examination systems-reliability, robustness and resilience (pp. 166-178). Amherst, NY: Cambria Press Inc.

Ley, T. C., Schaer, B. B., \& Dismukes, B. W. (1994). Longitudinal study of the reading attitudes and behaviors of middle school students. Reading Psychology: An International Quarterly, 15, 11-38. doi:10.1080/0270271940150102

McGinley, W., and Kamberelis, G. (1996). Maniac magee and ragtime timpie: Children negotiating self and world through reading and writing. Research in the Teaching of English, 30, 75-113.

Nielsen, J. (2005). Usability of websites for teenagers regardingTeenagers on the web: 60 usability guidelines for creating compelling web sites for teens. URL (last checked 21 July 2011) http://www.nngroup.com/reports/teens

Ögeyik, M. C., \& Akyay, E. (2009). Investigating reading habits and preferences of student teachers at foreign language departments. The International Journal of Language Society and Culture, 28 www.educ.utas.edu.au/users/tle/JOURNAL/

Sharma, A. K., \& Singh, S. P. (2005). Reading habits of faculty members in natural sciences: A case study of the University of Delhi. Annals of Library and Information Studies, 52, 119-123.

Smith, N., \& Robinson, H. (1980). Reading Instruction for today's children. Englewood Cliff, NJ: Prentice Hall Inc.

TGI (nd.). Nationwide healthcare staffing. URL (last checked 21 July 2011) http://www.techgroupin.com

Todd, R. K. (2003). Adolescents of the information age: Patterns of information seeking and use, and implications for information professionals. School Libraries Worldwide, 9, 27-46.

Wilson, R. J. (1985). Children's classics: A reading preference study of fifth and sixth graders. Dissertation Abstracts International, 47.

Wolfson, B. J., Manning, G., \& Manning, M. (1984). Revisiting what children say their reading interests are. Reading World, 24, 4-10. doi:10.1080/19388078409557812

Worthy, J., Moorman, M., \& Turner, M. (1999). What johnny likes to read is hard to find in school. Reading Research Quarterly, 34, 12-27. doi:10.1598/RRQ.34.1.2 